\title{
Ultrasound-guided steroid injection: A scintillating dimension in managing de Quervain's tenosynovitis
}

\author{
Ashish Mathew ${ }^{1, *}$, Latheesh Leo ${ }^{2}$ \\ ${ }^{1}$ PG Resident, Dept. of Orthopaedics, ${ }^{2}$ Unit Chief, Dept. of Hand and Microsurgery, Father Muller Medical College, Mangalore,
} Karnataka, India

*Corresponding Author:

Email: ash.9mathew@gmail.com

\begin{abstract}
Introduction: de Quervain's tenosynovitis is a stenosing tenosynovitis of the first extensor compartment of the wrist and leads to wrist pain along with impaired function of the wrist and hand. Local steroid injection and surgical release forms the mainstay treatment in the conservative and surgical line of treatment respectively till date. This study aims to bring out the effectiveness of local steroid injection given accurately under ultrasound guidance making it comparable to surgical release in the short term period, thereby emerging as an immediate and cost - effective line of management.

Materials and Methods: Twenty three patients diagnosed with de Quervain's tenosynovitis were included in this study whom did not show any relief of symptoms when conservative mode was used namely rest and analgesics and splinting in certain cases. Clinically patients were assessed using DASH score based on the severity of condition before the procedure and after the procedure. A mixture of $1 \mathrm{ml}$ of triamciniolone and $1 \mathrm{ml}$ of $1 \%$ lidocaine hydrochloride was taken under aseptic precautions and was injected into the involved compartment under expert guidance with help of ultrasound imaging. Clinical improvement was later evaluated by analyzing the pre procedural and post procedural DASH (Disabilities of the Arm, the Shoulder and the Hand) score indexes comparing it to surgical release. ${ }^{8}$

Results: 22 patients ( $96 \%$ were symptom-free) out of the 23 patients that were included, after the 1st injection at two weeks. At the end 6 months $22(96 \%)$ patients were symptom free and were fully satisfied with the gratifying outcome. No recurrence in these patients after a 1 year of follow-up was recorded.

The one failed patient underwent surgery for release of the first extensor compartment and was symptom-free at the 2 weeks post -op after assessment. Adverse reaction of the steroids were incidentally seen in $2 / 23(16 \%)$ of the patients, which eventually subsided in 20 weeks. Incidence of nerve injury, infection, or tendon rupture did not occur.

Conclusion: We draw to close that selective infiltration of steroids in the common sheath of the EPB and APL under Ultrasound -guidance provides an evocative improvement of pain and function in greater number of patients with de Quervain's Syndrome thereby avoiding a possible surgery.
\end{abstract}

Keyword: Ultrasound guided, infiltration, DASH.

\section{Introduction}

The genesis of name de Quervain's tenosynovitis is given after the Swiss surgeon Fritz de Quervain who revealed it in 1895 for the first time. He revealed five cases and later eight cases in 1912. Hoffmann who was a surgeon officially published an article in American literature in 1989.

Stenosing tenosynovitis of the first extensor compartment of the wrist, affecting the EPB and APL tendons sheath is referred to as de Quervain's syndrome. Repeated movements of the thumb fountainhead chronic microtrauma of low grade at the level of the radial styloid with repeated frequency that can lead to localized thickening of the extensor retinaculum of the wrist. This would subsequently thereby cause impingement and inflammation of the EPB and APL tendons. The formation of adhesions between the tendons and the sheath is the last stage of fibrotic reaction that develops in the compartment following effusion and thereby causes the obliteration of space in 1st extensor compartment forms the nexus of the syndrome. After thorough history and clinical examination (wrist pain, positive Finkelstein's test tenderness and swelling), a diagnosis is made but
Ultrasound can be helpful to confirm it. Ultrasound in majority of the cases would show thickening of the synovia and tendons, and intrasheath fluid.

Till date, there is no concord in the management of tenosynovitis and the treatment modalities like rest massage, cold and heat application, diathermy and splints are not effective in tenosynovitis. ${ }^{8}$ However the non-surgical treatment like bracing, physical therapy, thumb spica and local corticosteroids injections are most effective. ${ }^{8}$ Surgical treatment involves the release of the first extensor compartment of the wrist. Surgical release reported to be curative in $91 \%$ of patients, but it has been associated with higher costs and sometimes surgical complications. ${ }^{8}$ The purpose of this study is to know the efficacy of injecting corticosteroids injections for de Quervain's tenosynovitis when compared to surgical release. ${ }^{8}$

\section{Materials and Methods}

The study was conducted at the Department of Orthopaedics, Father Muller Medical College, Mangalore which analyzed the pain severity on the basis of DASH scoring of patients presenting to the OPD with complains of wrist pain and was diagnosed 
with de Quervain's tenosynovitis. The study was conducted from August 2016 to August 2017.

Cases with a documented history of pain over the radial aspect of the wrist, a documented physician's diagnosis of de Quervain's tenosynovitis, and a documented positive Finkelstein's test in the patient's medical record formed the paradigm of inclusion criteria.

Cases that were excluded were minor age less than 18 years, presence of a separate compartment for EPB, presence of an absolute contraindication for corticosteroid injection, prior treatment in the last six months with steroid injection and/or surgery for the same at the concerned anatomical location, and possible traumatic or neoplastic origin of symptoms.

Twenty three patients diagnosed with de Quervain's tenosynovitis were included in this study whom did not show any relief of symptoms when conservative mode was used namely rest and analgesics and splinting in certain cases. Clinically patients were assessed using DASH score based on the severity of condition before the procedure and after the procedure. A mixture of $1 \mathrm{ml}$ of triamciniolone and $1 \mathrm{ml}$ of $1 \%$ lidocaine hydrochloride was taken under aseptic precautions and was injected into the involved compartment under expert guidance with help of ultrasound imaging. ${ }^{4}$ Clinical improvement was later evaluated by analyzing the pre procedural and post procedural DASH (Disabilities of the Arm, the Shoulder and the Hand) score indexes comparing it to surgical release. ${ }^{8}$

Patients with de Quervain's Syndrome were analysed under ultrasound imaging and under sterile precautions, percutaneously the common tendon sheath of the EPB and the APL was selectively infiltrated with steroids using a $21 \mathrm{G}$ needle. Continuous ultrasound monitoring (with a 7-12 $\mathrm{MHz}$ linear transducer) delineated the correct anatomical location of the needle tip inside the tendon sheath and showed the intensifying intra sheath fluid distension.

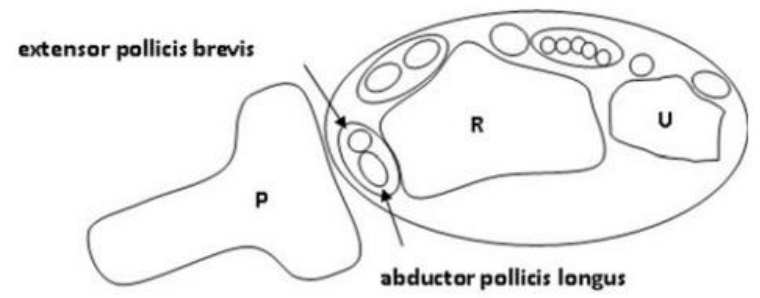

$\mathrm{P}=$ probe; $\mathrm{R}=$ radius; $\mathrm{U}=$ ulna

Fig. 1: The drawing shows the ultrasound probe potion over the first dorsal compartment that provides a transverse sonographic image to aid in ultrasound-guided injections for de Quervain's tenosynovitis

Clinical improvement was evaluated by comparing the pre procedural and post procedural clinical symptoms and disability according to DASH (Disabilities of the Arm, the Shoulder and the Hand) score indexes. ${ }^{2}$

The DASH Outcome Measure was scored after analyzing patient's severity on the basis of two sections of DASH scoring : the disability/symptom section (30 items, scored 1-5) and the optional high performance Sport/Music or Work section (4 items, scored 1-5). ${ }^{2}$

For early clinical response each patient examined two weeks after the injection, and then followed after 2 months and later at 6 months. By assessing reduction in severity of pain and tenderness on the radial side of wrist, negative Finkelstein test and patient satisfaction on the basis of DASH score, the treatment efficacy was computed. ${ }^{2}$
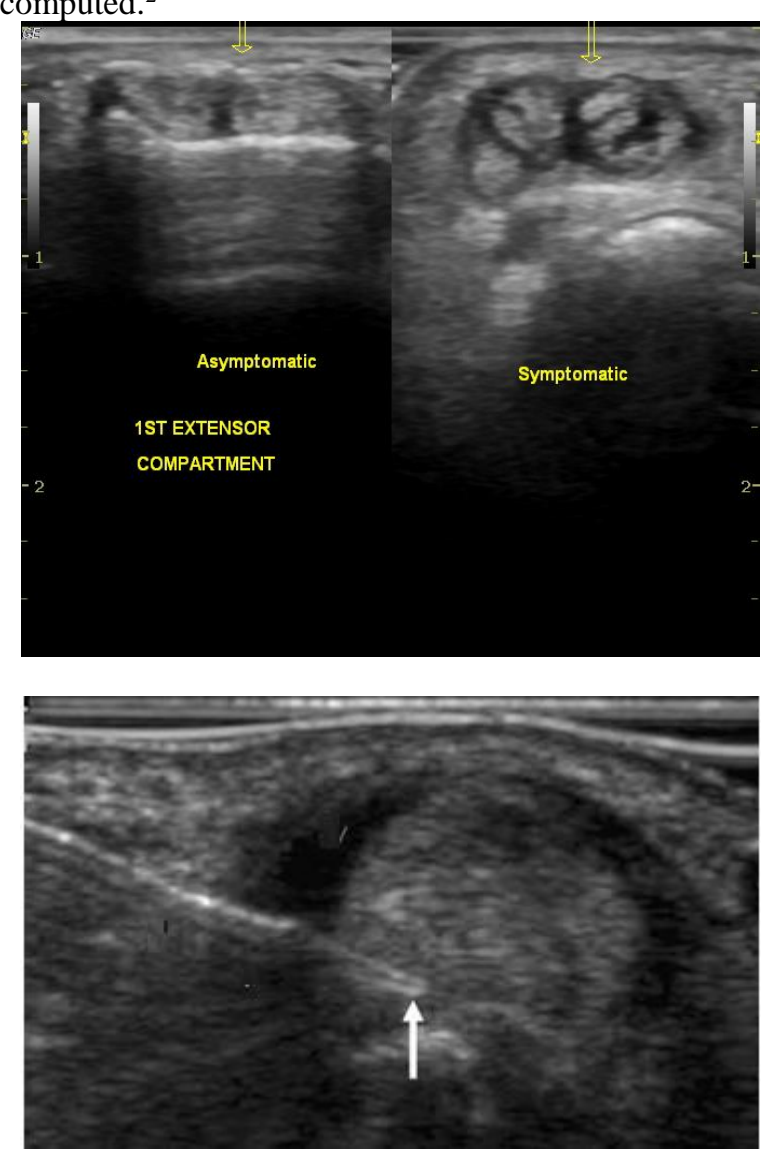

Fig. 2: Ultrasound image, at the time of delivery of injection into the $1^{\text {st }}$ extensor compartment
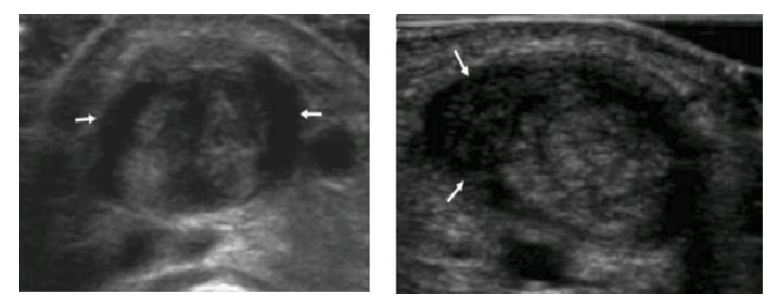

Fig. 3: Images before and after infiltration of steroid into the $1^{\text {st }}$ compartment

\section{Results}


Pre and post procedure analysis of pain severity on the basis of DASH score when the patient came for follow -up were computed and analysed.

22 patients (96\% were symptom-free) out of the 23 patients that were included, after the 1 st injection at two weeks. At the end 6 months $22(96 \%)$ patients were symptom free and were fully satisfied with the gratifying outcome. No recurrence in these patients after a 1 year of follow-up was recorded.

The one failed patient underwent surgery for release of the first extensor compartment and was symptom-free at the 2 weeks post -op after assessment. Adverse reaction of the steroids were incidentally seen in $2 / 23(16 \%)$ of the patients, which eventually subsided in 20 weeks. Incidence of nerve injury, infection, or tendon rupture did not occur.

Table 1

\begin{tabular}{|l|c|c|}
\hline \multicolumn{1}{|c|}{ Dash Scores } & Cases: 23 & Cases: 23 \\
\hline & $\begin{array}{c}\text { Ultrasound } \\
\text { guided } \\
\text { injection }\end{array}$ & $\begin{array}{c}\text { Surgical } \\
\text { release }\end{array}$ \\
\hline Pre-procedure & 58.4 & 57.6 \\
\hline 2 weeks post procedure & 12.8 & 10.6 \\
\hline $\begin{array}{l}2 \text { months } \\
\text { post procedure }\end{array}$ & 13 & 11 \\
\hline $\begin{array}{l}\text { 6 months post } \\
\text { procedure }\end{array}$ & 13 & 11 \\
\hline
\end{tabular}

\section{Graph 1}

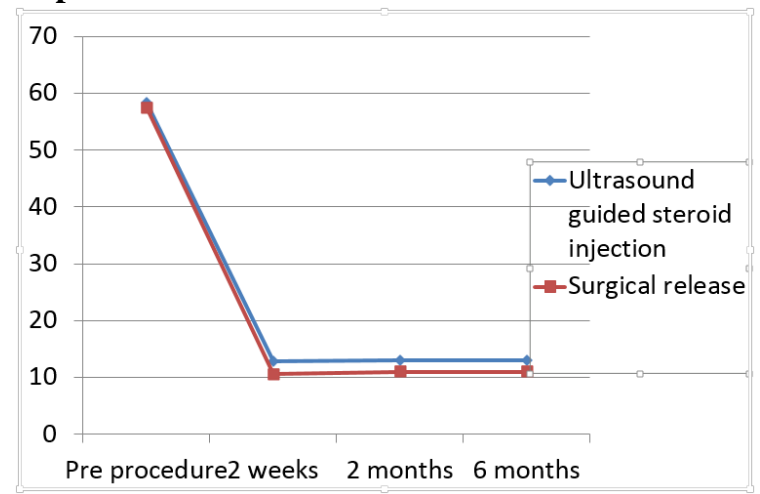

\section{Graph 2}

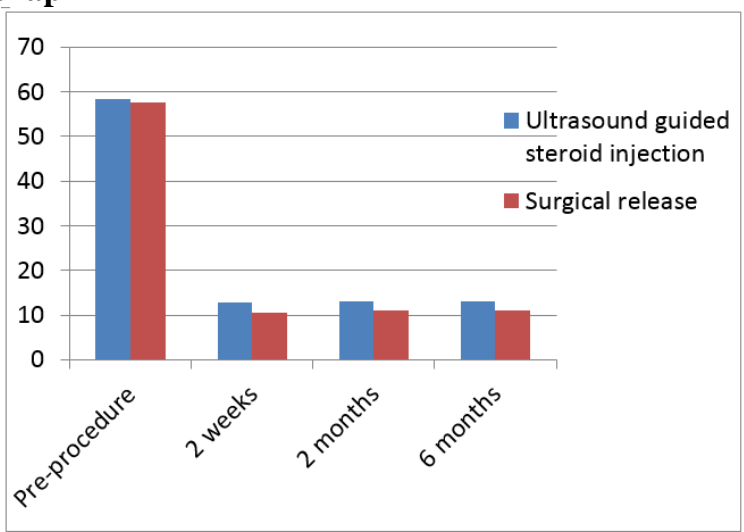

\section{Discussion}

When sub-compartmentalization is present within first extensor compartment in patients with de Quervain tenosynovitis, the EPB side is often more severely affected than the APL side. ${ }^{16}$ Thus, patients with this variation who receive steroid injections limited to subcompartments may not respond to therapy. ${ }^{16}$

Ultrasound is a worthwhile preoperative investigation in case of de Quervain's disease. It can provide objective and documented proof of the diagnosis and can act as a guide to choose the mode of management (conservative or surgical). ${ }^{16}$

Given that response to treatment is related to injection accuracy and anatomic variation, ultrasoundguided injections have emanated as an option in the non-operative management of de Quervain's disease. ${ }^{4}$

Selected Characteristics of various studies in the treatment of de Quervain's Tenosynovitis ${ }^{17}$

\begin{tabular}{|c|c|c|c|c|c|c|c|}
\hline Parameter & 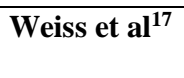 & $\begin{array}{c}\text { Harvey et } \\
\text { al }^{17}\end{array}$ & $\begin{array}{c}\text { Anderson et } \\
\text { al }^{17}\end{array}$ & $\underset{17}{\text { Witt et al. }}$ & Mckenzie $^{17}$ & $\begin{array}{c}\text { Zingas et } \\
\text { al }^{17}\end{array}$ & $\begin{array}{l}\text { Current } \\
\text { study }\end{array}$ \\
\hline Female & 80 & 70 & 50 & 64 & 25 & 12 & 23 \\
\hline Male & 13 & 12 & 5 & 19 & 5 & 7 & 0 \\
\hline $\begin{array}{l}\text { Bilateral } \\
\text { wrist }\end{array}$ & 0 & 0 & 1 & 4 & 0 & 0 & 0 \\
\hline Age (Mean) & 38 & 45 & 47 & 44 & 49.5 & 39 & 47 \\
\hline $\begin{array}{l}\text { Diagnostic } \\
\text { Criteria }\end{array}$ & $\begin{array}{l}\text { Pain at radial } \\
\text { wrist, } 1^{\text {st }} \\
\text { extensor } \\
\text { compartment } \\
\text { tenderness } \\
\text { Finkelstein's } \\
\text { test positive }\end{array}$ & $\begin{array}{l}\text { Pain at radial } \\
\text { wrist, } 1^{\text {st }} \\
\text { extensor } \\
\text { compartment } \\
\text { tenderness } \\
\text { Finkelstein's } \\
\text { test positive }\end{array}$ & $\begin{array}{l}\text { Pain at radial } \\
\text { wrist, } 1^{\text {st }} \\
\text { extensor } \\
\text { compartment } \\
\text { tenderness } \\
\text { Finkelstein's } \\
\text { test positive }\end{array}$ & $\begin{array}{c}\text { Pain at } \\
\text { radial } \\
\text { wrist, } 1^{\text {st }} \\
\text { extensor } \\
\text { compartm } \\
\text { ent } \\
\text { tenderness }\end{array}$ & $\begin{array}{l}\text { Pain at radial } \\
\text { wrist, } 1^{\text {st }} \\
\text { extensor } \\
\text { compartment } \\
\text { tenderness } \\
\text { Finkelstein's } \\
\text { test positive }\end{array}$ & $\begin{array}{l}\text { Pain at radial } \\
\text { wrist, } 1^{\text {st }} \\
\text { extensor } \\
\text { compartment } \\
\text { tenderness } \\
\text { Finkelstein's } \\
\text { test positive }\end{array}$ & $\begin{array}{l}\text { Pain at radial } \\
\text { wrist, } 1^{\text {st }} \\
\text { extensor } \\
\text { compartment } \\
\text { tenderness } \\
\text { Finkelstein's } \\
\text { test positive. }\end{array}$ \\
\hline
\end{tabular}




\begin{tabular}{|l|c|c|c|c|c|c|c|}
\hline & & & & $\begin{array}{c}\text { Finkelstei } \\
\text { n's test } \\
\text { positive }\end{array}$ & & \\
\hline $\begin{array}{l}\text { Injection: } \\
\text { Medication } \\
\text { used }\end{array}$ & $\begin{array}{c}1 \mathrm{ml} \\
\text { Betamthason } \\
\text { e, } 1 \mathrm{ml} 1 \% \\
\text { lidocaine }\end{array}$ & $\begin{array}{c}\text { Hydocortiso } \\
\text { ne acetate or } \\
\text { Methyl } \\
\text { Prednisolone } \\
\text { acetate, } \\
\text { Local } \\
\text { anaesthetic }\end{array}$ & $\begin{array}{c}80 \mathrm{mg} \text { Methyl } \\
\text { prednisolone } \\
1.5 \mathrm{ml} 1 \% \\
\text { Xylocaine }\end{array}$ & $\begin{array}{c}40 \mathrm{mg} \\
\text { Methyl } \\
\text { prednisolo } \\
\text { ne }, 1 \mathrm{ml} \\
1 \% \\
\text { Xylocaine }\end{array}$ & $\begin{array}{c}25 \mathrm{mg} \\
\text { hydrocortiso } \\
\text { ne, } 1 \mathrm{ml} 2 \% \\
\text { Xylocaine }\end{array}$ & $\begin{array}{c}6 \mathrm{mg} \\
\text { celestone } \\
3 \mathrm{ml} 1 \% \\
\text { lidocaine }\end{array}$ & $\begin{array}{c}1 \mathrm{ml} \text { of } \\
\text { triamciniolon } \\
\text { e and 1 ml of } \\
1 \% \text { lidocaine } \\
\text { hydrochloride }\end{array}$ \\
\hline $\begin{array}{l}\text { One } \\
\text { Injection }\end{array}$ & 42 & 45 & 33 & 87 & 24 & 19 & 23 \\
\hline $\begin{array}{l}\text { Repeat } \\
\text { Injection }\end{array}$ & 0 & 7 & 14 & 0 & 5 & 0 & 0 \\
\hline $\begin{array}{l}\text { Percentage } \\
\text { of success }\end{array}$ & 67 & 82 & 90 & 62 & 93 & 58 & 96 \\
\hline $\begin{array}{l}\text { Failure } \\
\text { (No.of } \\
\text { Patients) }\end{array}$ & $45($ all & 11 & 5 & $\begin{array}{c}33(30 \\
\text { underwent } \\
\text { surgery })\end{array}$ & 1 & 8 & 1 \\
\hline $\begin{array}{l}\text { Follow Up } \\
\text { (Months) }\end{array}$ & 4,13 & $0,5,20$ & $1,5,18$ & 18 & $0,5,1,3$ & 1,3 & $0.5,2,6$ \\
\hline
\end{tabular}

\section{Conclusion}

Given that response to treatment is related to injection accuracy and anatomic variation, ${ }^{16}$

Ultrasound-guided injections have emanated as an option in the management of de Quervain's disease as a less invasive and cost-effective modality compared to surgical release.

This would thereby encourage patients to opt for a less invasive procedure. We draw to close that selective infiltration of steroids in the common sheath of the EPB and APL under Ultrasound -guidance provides an evocative improvement of pain and function in greater number of patients with de Quervain's Syndrome thereby avoiding a possible surgery.

\section{References}

1. Inês, L. and da Silva, J. (2005). Soft tissue injections. Best Practice \&amp; Research Clinical Rheumatology, 19(3), pp.503-527.

2. Di Sante, L., Martino, M., Manganiello, I., Tognolo, L. and Santilli, V. (2013). Ultrasound-Guided Corticosteroid Injection for the Treatment of de Quervain's Tenosynovitis. American Journal of Physical Medicine \&amp; Rehabilitation, 92(7), pp.637-8.

3. Peters-Veluthamaningal, C., Winters, J., Groenier, K. and Meyboom-deJong, B. (2009). Randomised controlled trial of local corticosteroid injections for de Quervain\&\#39;s tenosynovitis in general practice. BMC Musculoskeletal Disorders, 10(1).

4. JeyapalanKchoudhary S. Ultrasound-guided injection of Triamcinolone and Bupivacaine in the Management of de Quervain's disease. Skeletal Radiology, 2009;38(11):1099-103.

5. 5 .Rowland, P., Phelan, N., Gardiner, S., Linton, K. and Galvin, R. (2015). The Effectiveness of Corticosteroid Injection for De Quervain's Stenosing

Tenosynovitis(DQST): A Systematic Review and MetaAnalysis. The Open Orthopaedics Journal,9(1), pp.43744.

6. Coombes B, Bisset L, Vicenzino B. Efficacy and Safety of Corticosteroid injections and other injections for management of Tendinopathy: A Systematic Review ofRandomised Controlled Trials. The Lancet 2010;376(9754):1751-67.

7. Kamel, M. (2002). Ultrasonographic diagnosis of de Quervain\&\#39;s tenosynovitis. Annals of the Rheumatic Diseases, 61(11), pp.1034-35.

8. Akram M, Latif Shahzad M, MubashirFarooqi F, Irshad M, Kumar Sah R, Muhammad Awais S. Results of Injection Corticosteroids in Treatment of de Quervain's Tenosynovitis.JMPA. 2016;64(s-30).

9. Shivanna D, Manjunath D, Holagundi L, Kumar HV M. Outcome of Intra-sheath Steroid Injection for de Quervain's Tenosynovitis. The Internet Journal of Hand Surgery. 2014;6(1).

10. V, M., B M, M. and S V, M. (2015). Intra Sheath Steroid Injections in Management of de quervain's tenosynovitis. journal of evidence based medicine and healthcare, 2(57), pp.8892-3.

11. Lee, H., Kim, P., Aminata, I., Hong, H., Yoon, J. and Jeon, I. (2014). Surgical Release of the First Extensor Compartment for Refractory de Quervain\&\#39;s Tenosynovitis: Surgical Findings and Functional Evaluation Using DASH Scores. Clinics in Orthopedic Surgery,6(4), p.405.

12. Ta, K., Eidelman, D. and Thomson, J. (1999). Patient satisfaction and outcomes of surgery for de Quervain\&\#39; tenosynovitis. The Journal of Hand Surgery, 24(5), pp.1071-7.

13. Scheller, A., Schuh, R., Hönle, W. and Schuh, A. (2008). Long-term results of surgical release of de Quervain'sstenosing tenosynovitis. International Orthopaedics, 33(5), pp.1301-3.

14. Yuasa, K. and Kiyoshige, Y. (1998). Limited surgical treatment of de quervain\&\#39;s disease: Decompression of only the extensor pollicis brevis subcompartment. The Journal of Hand Surgery, 23(5), pp.840-3.

15. de Quervain disease: Ultrasound identification of Anatomic Variations in the First Extensor Compartment with An Emphasis on Subcompartmentalization supplemental material: http://radiology.rsna.org/lookup/suppl/doi:10.1148/radiol. $11102458 /-/ \mathrm{dc} 1$

16. Kamath, B., Kamath, K., Kumar, A., Shetty, M. and Bhardwaj, P. (2016). Preoperative ultrasound in de 
Quervain's disease: an investigation worth doing. Journal of Hand and Microsurgery, 01(01), pp.12-6.

17. McDermott JD, Ilyas AM, Nazarian LN, Leinberry CF. Ultrasound-guided Injections for de Quervain's Tenosynovitis. Clinical Orthopaedics and Related Research. 2012;470(7):1925-1931. doi:10.1007/s11999012-2369-5. 